\title{
PLANO DE NEGÓCIOS: UMA GESTÃO EFICIENTE
}

Congresso Nacional Online de Empreendedorismo, 3a edição, de 06/12/2021 a 08/12/2021 ISBN dos Anais: 978-65-81152-30-7

NOVAK; Jaqueline de Araújo Gama Novak 1, CUNHA; Gina Mello da Cunha 2, BARBOSA; Mauricéa Serino Barbosa ${ }^{3}$, COSTA; Renan Augusto de Mello ${ }^{4}$, ÁVILA; Wellington 5

\section{RESUMO}

Buscou-se apresentar a partir da temática abordar a importância das ferramentas do plano de negócio, pois quando bem estruturado o empresário ou empreendedor consegue alcançar um melhor planejamento e direcionamento de suas idéias tornando-as mais assertivas para o seu negócio, como também estabelecer metas para evitar possivéis riscos. O presente trabalho se objetiva apresentar como diferencial o plano de negócio de maneira que o empreendedor consiga trabalhar munido de uma melhor estratégia em seus negócios, assim permitindo o sucesso, potencializando a geração de emprego, proporcionando independência financeira e contribuindo também para o crescimento da economia. Foi realizada uma pesquisa bibliográfica e logo após a revisão de literatura pertinente aos estudos propostos na temática, finalizando com uma breve análise comparativa dos negócios que atestaram seguir categoricamente o preconizado nos respectivos planos de negócios. Foi identificado que o plano de negócio possui diferencial nas empresas que o possuem como auxílio no crescimento do novo empreendimento e também na adoção de mudanças estratégicas de empresas já em operação, ele ajuda na conquista do público proporcionando diferencial em relação ao mercado competitivo. Os passos para um bom plano de negócio se resumem em analisar o mercado, conhecer o público alvo e os concorrentes. Cabe ressaltar que o plano de negócio é uma poderosa ferramenta usada para gerenciar negócios potencializando assim as chances de sucesso em diversas formas, estabelecendo a visão geral do negócio desenhado no plano, sua aplicação, seus prazos e objetivos, assim idealizando a melhor estrutura, conhecendo custos e despesas, visualizando diferentes cenários e previsões de faturamento da empresa. É simplesmente uma peça fundamental para a empresa se manter saudável, duradoura e sustentável, fortalecendo com a sua qualidade de elaboração os fatores favoráveis aos esperados lucros e posicionamento no mercado.

PALAVRAS-CHAVE: Direcionamento, Estratégia, Gestão Eficiente, Plano de Negócio, Sucesso 